\title{
A kétlépcsős onkoteam müködése, avagy a társas intelligencia a rákgyógyítás szolgálatában és a kiégés megelőzésében
}

\author{
Sárkány Henrik ${ }^{1}$ - Forgács-Menyhért Mónika ${ }^{1,2}$ - Hajnal András dr. ${ }^{3}$ \\ Kövér Erika dr. ${ }^{1}$. Mangel László dr. ${ }^{1}$ \\ ${ }^{1}$ Pécsi Tudományegyetem, Általános Orvostudományi Kar, Klinikai Központ, Onkoterápiás Intézet, Pécs \\ ${ }^{2}$ Pécsi Tudományegyetem, Általános Orvostudományi Kar, Alapellátási Intézet és Palliatív Medicina Tanszék, Pécs \\ ${ }^{3}$ Pécsi Tudományegyetem, Általános Orvostudományi Kar, Klinikai Központ, \\ Pszichiátriai és Pszichoterápiás Klinika, Pécs
}

Bevezetés és célkitüzések: Az együttmúködés, a csoportmunka életünk szinte minden területén képes növelni a hatékonyságot. A rákgyógyításban már évtizedek óta alkalmazott onkoteamek múködését vizsgálva, annak egyértelmú célja az orvosi hatékonyság, az egymástól tanulás és a jogi védelem biztosítása. Jelenleg egy másik aspektust hangsúlyozva próbáljuk bemutatni a kooperatív munka múködését, megvilágítva a kommunikációban részt vevők lehetőségeit és dilemmáit, illetve legfóképpen a pszichés támogató hatást.

Módszer és eredmények: A Pécsi Tudományegyetem Klinikai Központjának Onkoterápiás Intézetében 12 éve múködik a kétlépcsős onkoteamrendszer. Az onkoterápiás megbeszéléseken egyéves időszak alatt 21 orvos, több adminisztrátor, klinikai kutatási munkatárs, szakdolgozó, gyógyszerész és pszichológus vett részt, a résztvevő́k szakmai tapasztalata igen széles spektrumot fedett le. A megbeszélések során az egyes betegek onkológiai életútja került részletes diszkusszióra interaktív formában, végül a döntési részletek rögzítésre kerültek a központi informatikai rendszerben. Megfigyeléseink rávilágítottak a csapatmunka előnyeire, illetve a csoport által ellátott feladatok megosztó, kiegyensúlyozó, oktatást segítő hatásaira. Az orvosok által kitöltött kérdőívek pedig bizonyították, hogy a közvetlen munkatársak közötti szakmai megbeszélés, egyféle „Bálint-csoport” múködésként a pszichés terhek megosztásában is szerepet játszhat.

Következtetés: A rákgyógyítás területén az elmúlt évek során bekövetkezett gyors fejlődés, a fokozott elvárások, illetve az ezen a területen végzett, sokszor igen összetett és lelkileg is megterhelő szakmai munka kiemelten fontossá teszi a hatékony minőségbiztosítási módszerek és együttmúködési formák alkalmazását, melyek segítségével lehetőség nyílik a szakmai eszmecseréken át a többirányú tudástranszferre és a kiégést megelőző csoportventilációra.

Orv Hetil. 2021; 162(9): 344-351.

Kulcsszavak: onkoteam, kooperáció, társas intelligencia, rákgyógyítás, kiégés

\section{Two-level tumor board operation-based social intelligence that serves the quality of cancer treatment and the prevention of burnout phenomenon}

Introduction: The teamwork, the cooperation is always able to elevate effectiveness in every field of life. The tumor board meetings which are widely used in cancer treatment process in the last decades were originally established to warrant the medical, educational and legal quality assurance. Over these aspects, here we present the possibilities and dilemmas of the team work in the communication practices and most of all the psychological support of the participants.

Method and results: The two-level oncotherapy tumor board system was introduced 12 years ago at the Institute of Oncotherapy, Clinical Center, University of Pécs. During a one-year long observation period, 21 physicians and several administrators, study coordinators, pharmacists, nurses and psychologists with different experiences participated in the oncotherapy tumor board discussions. In the meetings, the specific cancer histories of the patients were analyzed in an interactive form, and finally the detailed decisions were stored in the medical database system. Our observations proved the advantages, moreover, the task sharing, balancing and educational effects of the teamwork. 
The results obtained from the questionnaires filled out by the physicians proved that the direct conversation between department colleagues works like a case-discussing "Bálint-group" in taking the role of distributing of the psychological burden of the physicians.

Conclusion: The immense advancements in cancer treatment during the last years, moreover, the increased expectations and the complex and mentally charging professional tasks all demand the establishment of more effective quality control and cooperation methods. Introducing these new methods, it would lead to more efficient professional discussions, knowledge transfer and burnout preventive group-related psychological ventilation.

Keywords: tumor board, cooperation, social intelligence, cancer treatment, burnout

Sárkány H, Forgács-Menyhért M, Hajnal A, Kövér E, Mangel L. [Two-level tumor board operation-based social intelligence that serves the quality of cancer treatment and the prevention of burnout phenomenon]. Orv Hetil. $2021 ; 162(9): 344-351$.

(Beérkezett: 2020. augusztus 10; elfogadva: 2020. szeptember 22.)

\section{Rövidítések}

EFOP = Emberi Erőforrás Fejlesztési Operatív Program; GINOP = Gazdaságfejlesztési és Innovációs Operatív Program; VEKOP = Versenyképes Közép-Magyarország Operatív Program

A rákgyógyítás az elmúlt egy-két évtized során hatalmas fejlődésen, alapvető változásokon ment át, és az újabb, hatékonyabb eljárások alkalmazásával, ugyanakkor a betegközpontú szemlélet megjelenésével összetettsége oly mértékben megnőtt, hogy ez elengedhetetlenné tette új egészségszervezési formák és minőségbiztosítási módszerek bevezetését, melyek képesek kiszolgálni a gyógyulás védelmében hozott erófeszítéseket [1]. A fenti folyamat részeként az orvosszakma a társas intelligenciát felhasználva terjesztette ki az egyén, azaz a gyógyító orvos képességeinek határát a heterogén csoportok kooperatív előnyeit biztosító, a múködés hatékonyságát növelő módszertani elemmel, a multidiszciplináris (többszakmás) onkoteamek (az angol nyelvű szakirodalomban 'tumor board'-ok) bevezetésével. Az onkoteameken belül különböző speciális szakterületek, illetve a gyógyítás, a rehabilitáció és az ápolás képviselői dolgoznak együtt, ami elengedhetetlen feltétele a megfelelő szakmai múködésnek [1-4]. A módszer hatékonyságát a benne részt vevő szakemberek szakmai, tapasztalati és sokszor nézetbeli különbözősége szolgáltatja. Az onkoteamek feladata, hogy megtalálják a beteg számára optimális gyógymódot, melynek segítségével a páciens állapota a lehető leghosszabb távon stabilizálható, javítható. A csoportmunka előnye az egyéni orvosi múködéssel szemben abban mutatkozik meg, hogy a beteg egészségi állapotát figyelembe véve, hatékony kommunikációt feltételezve, az egyre szélesedő szakmai tudás és tapasztalat alapján képes meghozni komplex döntését [1-4]. Persze az onkoteamek múködésével kapcsolatban számtalan kérdés, illetve szakmai, etikai, financiális bizonytalanság merülhet fel, és a döntési biztonság, továbbá a terápiás kivitelezhetőség is sokszor nehézségekbe ütközik $[1,2,5,6]$.
E világszerte elfogadott orvosi terápiás bizottságok mellett a Pécsi Tudományegyetemen több mint 12 éve alakult ki az ún. kettős onkoteamrendszer. Második lépcsőként az Onkoterápiás Intézetben múködik még egy, ún. onkoterápiás vagy belső onkoteam, amely egyfajta „jó gyakorlat” alapján a nem sebészi onkológiai gyógyítási folyamathoz szükséges minden szakértelemmel rendelkezik. Ezen pécsi rendszer múködéséről már 2012ben beszámoltunk az Orvosi Hetilap hasábjain, és egyúttal utalunk a tavalyi évben létrehozott pécsi palliatív onkoteam tapasztalataira is $[7,8]$. Ez a második lépcsős onkoteamrendszer azonban nemcsak a gyógyítás esélyeit javító orvosi minóségbiztosító fórum, hanem egyúttal intenzív oktatási és egy munkaközösségen belüli pszichés ventilációs lehetőség, amely egyfajta „Bálintcsoportként” a kollégák lelki egyensúlyának megtartásában is szerepet játszhat.

Célunk a jelen közleményben megvilágítani a rákgyógyítás folyamatában megjelenő együttmúködés előnyeit, annak nehézségeit, továbbá tervünk a gyógyítási és oktatási folyamatot is ellátó, többszakmás és onkoterápiás onkoteamen belül a különböző pszichés folyamatok, a csoportdinamika elemzése, értelmezése. Az együttmúködés előnyeinek és az orvosi múködést segítő pszichés hatásainak igazolása céljából egy kérdőív kitöltését is kértük a részt vevő orvoskollégáktól. Más szempontból a jelen tanulmány keretében az onkoteamrendszer részletes ismertetésén túlmenően az onkoteam-megbeszéléseken részt vevő külső szakértő és a pszichológus tapasztalatait is szeretnénk összefoglalni.

\section{Módszerek és eredmények}

\section{Az onkoteammüködésrôl általában}

A Pécsi Tudományegyetem Klinikai Központjában a közlemény megírásának idején összesen 13, nevesített, különböző szakemberekből álló, többszakmás team koordinálja a rákgyógyítást. Ezek tagjai az adott onkoteam múködésének megfelelően a daganatspecifikus se- 
bész és belgyógyász szakorvosok, klinikai onkológus, sugárterápiás szakember, patológus és radiológus szakorvos, illetve esetleg genetikus, pszichológus, palliatív orvos vagy más szakember.

Az Onkoterápiás Intézetben a multidiszciplináris onkológiai munkacsoport javaslatát ismételt szakmai megbeszélésen kemoterápiás és sugárterápiás szakemberek részvételével egy belső onkoteam újra véleményezi, jóváhagyja, illetve meghatározza az onkoterápia minden részletét, miután az onkológus kezelőorvos már találkozott a beteggel, megítélte a valós terápiás lehetőségeket, és felmérte a beteg igényeit, elvárásait. Az onkoterápiás onkoteam-megbeszéléseket heti három alkalommal rendezik meg, alkalmanként akár 20-30 beteg részletes kezelési terve kerül megbeszélésre kb. egy- (másfél) órás időtartamban. Természetesen a nagyobbrészt „rutinesetek" átbeszélése nem vesz igénybe 1-2 percnél többet, azonban a szakmailag problémás és/vagy lelkileg nehezebben feldolgozható esetekben mindig próbálunk több időt hagyni a diszkusszióra.

A teammunka helyszínének központjában egy asztalnál 12 fó foglal helyet (ez a fajta elrendezés a Bálint-csoport múködésében is alapvető szempont). A csoport munkáját segítő személyek az asztal körül elhelyezkedve figyelhetik a közös döntéshozatalt. Ezen munkában az elmúlt kb. egy év során 17 szakorvos, 4 rezidens vett részt; a szakorvosok jelentős része kemoterápiás és sugárterápiás szakvizsgával is rendelkezik. Az onkoteam tagjai között képviselve vannak a szúkebb értelemben vett onkológiai szakma szakorvosai mellett az ő munkájukat segítő, ápolói, gyógyszerészi, vizsgálati koordinátori és adminisztratív feladatokat ellátó kollégák is. A megbeszéléseket a kijelölt vezető koordinálja. A belső onkoteam-megbeszélésen a feladat a betegek részletes kezelésével kapcsolatos orvosszakmai döntések megvitatása és konszenzuson alapuló döntéshozatal. A beteggel kapcsolatot tartó szakorvos az első lépésben ismerteti az előzményeket, javaslatát pedig a team teljes egészében elfogadja, vagy módosításokat javasol. A vonatkozó orvosi dokumentáció részleteit a résztvevők kivetítőn kísérhetik figyelemmel, itt a releváns orvosi információk kerülnek megjelenítésre. A rendelkezésre álló időkeretben kiemelten fontos a hatékony kommunikáció, és minden információnak rendelkezésre kell állnia, hogy szakmai szempontok alapján az optimális terápiás javaslat születhessen meg. A munka intenzitását illetően itt lehet megemlíteni, hogy egy év alatt általában átlagosan 25003000 döntés születik meg 1500-2000 kezelt betegre vonatkozóan.

Egy orvosírnok rögzíti a team döntését egy erre a célra kialakított, webalapú informatikai adatbázisban. Az adatbázisban már előzetesen felvételre került többek közt az onkológiai betegség típusa, a szövettani részletek, a releváns kórelőzmény, a kísérő betegségek, a betegtörténetet leíró fontosabb orvosi beavatkozások, a gyógyszeres kezelések és a beteg általános állapotára vonatkozó paraméterek is. A terápia szempontjából a leg- meghatározóbb a „tervezett terápia” rész, melyben a beteget ellátó orvos a vonatkozó szakmai irányelvek alapján, az általa a beteggel (és a többszakmás onkoteammel) korábban egyeztetett, részletes terápiás kezelésre tesz javaslatot, melyet ismertet a team résztvevőivel. Az együttmúködés lényege, hogy a résztvevők értékelik a javaslatot, szükség esetén javaslatot tesznek annak részben vagy egészben történő módosítására, illetve a meghatározott terápia pontos részleteire. A döntések során itt is megkülönböztethető a konkrét terápiás kezelésekről hozott döntés, melyben rögzítésre kerül, hogy mely terápiatípus, milyen gyakorisággal és milyen dózisban kerül alkalmazásra, illetve természetesen létezik további vizsgálatokat vagy konzultációkat szorgalmazó döntési kategória.

\section{Az onkoteam résztvevői pszichológiai szempontból}

A döntéshozatali mechanizmusban részt vevők aktivitásukat tekintve két fó csoportra oszthatók: az onkoteam munkájában tevékenyen részt vevő, aktív szerepkörrel rendelkezőkre, illetve a csoport munkáját támogató, segítő személyekre. A valódi konszenzusos döntés kialakításában minden esetben megjelenik a beteg véleménye, akarata is, melyet a szakorvos felelőssége a döntéshozók elé tárni. Az intézetben múködő kettős onkoteamrendszer második beiktatott döntési elemeként szolgáló belső onkoteam-megbeszélés alkalmával a betegek képviseletét a szakorvosa látja el közvetett úton, s bár a multidiszciplináris onkoteam esetén a beteg is aktív résztvevője lehet a döntéshozatali folyamatnak, ez a valós életben mégis ritkán történik meg, így a beteg igénye még közvetett módon sem jelenik meg, hiszen itt a beutaló orvos többnyire nincs tisztában az onkoterápiás lehetőségekkel.

Az onkoteamtagok tapasztalatán kívül az egyes résztvevők habitusa is sokban befolyásolhatja a csoport müködését és hatékonyságát. Az onkoteam alapvetően demokratikus intézmény, hiszen minden résztvevőnek van egyféle szavazati, hozzászólási jogköre, mégis rendkívül fontos a csoportvezető szerepe, személyisége és tapasztalata, hiszen moderátorként végig koncentrálva kell, hogy fenntartsa a hatékony csapatmunkát. Erre a feladatkörre csak határozott személyiség lehet alkalmas, hiszen egyrészt egyre több, tudományos és betegségtörténettel kapcsolatos információt kell, hogy megosszunk egymással, és egyre több a beteg és az eset, másrészt a döntéseknek komoly súlyuk van, ezek emberi sorsokat, gyógyulási esélyeket határoznak meg. Persze a team vezetőjének támogatásra van szüksége, hiszen csak az együttmúködési szándék teremthet meg sok-sok helyes orvosi döntést. Természetesen az aktív, állandó résztvevők habitusa is igen különböző lehet, léteznek magabiztos-határozott, bizonytalan-aggódó, szétszórt-támogatásra szoruló és érdektelen-közönyös attitűdök. Ezek nem állandó kategóriák, változhatnak és vegyülhetnek, de ezek határozzák meg a közös döntési múködést. A végső döntést per- 
sze részben a közös gondolkodás és tudás, részben - nem mellesleg - a legtapasztaltabb és leghatározottabb résztvevők véleménye határozza meg.

\section{Az onkoteam oktatási szerepe}

Az onkoteam elsődleges célja a rákgyógyítás során alkalmazható terápiás lehetőségek közül a beteg számára optimális kiválasztása. A folyamat során számos lehetőség kínálkozik a kommunikációs csatornák múködtetésére, melyek közül az egyik legfontosabb a tanulási folyamatok biztosítása. A csoporttagok egymással történő interakcióik folytán pozitív és negatív visszacsatolási mechanizmusok révén hatást gyakorolnak egymás szakmai fejlődésére. A döntéshozatali mechanizmusok megfigyelése ugyanakkor kiváló alkalmat nyújt az elméleti és gyakorlati tudásanyag ismétlésére, elsajátítására, bővítésére [9]. A csoport múködése során elhangzó információk, megjelenő attitűdök nagyban hozzájárulnak a csoportot figyelő rezidens orvosok személyiségének formálásához, szakmai tapasztalatainak bővítéséhez. A fentieket tekintve a csoportmúködés során nagyon fontos a megfelelő hozzáállás közvetítése a csoport munkáját figyelő fiatal orvosok felé, hiszen a csoport a szakmai színvonal hoszszú távú fenntartásáért is felelősséggel tartozik, segítve a rezidens orvosokat gyakorlati tapasztalataik bővítésében. Az onkoteam ily módon közvetve jelentős hatást gyakorol a jövő onkológusnemzedéke attitüdjének és orvosszakmai tudásának formálására is. Az onkoteam-megbeszélések további célja, hogy a csoporttagok orvosszakmai munkájában felmerülő különbségeket mérsékelje azáltal, hogy lehetőséget biztosít a nyílt és őszinte kommunikáción keresztül a különböző terápiás eljárások okozta nehézségek megítélésére is.

\section{Az onkoteamek értékelése}

Az előzőekben említett pécsi múködésnek megfelelően kérdőíves vizsgálatot végeztünk az elmúlt 2-3 évben az onkoteam-megbeszéléseken rendszeresen részt vevő kollégák között. A kérdőívre 3 kolléga nem válaszolt, a 16 válaszoló közül kettő nem az intézet dolgozója (szakvizsgaidőszakot töltöttek itt), 4-en szakorvosjelöltek, 10-en szakorvosok. A kérdéseket úgy állítottuk össze, hogy azok magukban foglalják az onkoteam-megbeszélések oktatási (1. Fontos a tudásmegosztás, az egymástól tanulás; 2. Hatékony módszer a szakorvosjelöltek oktatására), jogi-felelősségi (3. Jogi biztonságot ad a kezelőorvos számára; 4. A döntés fontos része az orvosi felelősség megosztása), betegjogi (5. A beteg számára optimális terápia így választható ki; 6 . A beteg saját elvárása is beépíthető a döntésbe), szakmabiztonsági (7. Új innovatív diagnosztika/terápia így hatékonyabban meghatározható; 8. Evidenciaalapú, protokolláris terápiás döntés érhető el), pszichológiai (9. Csökkenti a kezelőorvos pszichés terheit, érzelmi bizonytalanságát; 10. Teret hagy a saját gondolatoknak, érzéseknek) és közösségi-problémameg- oldó (11. A csapatmunka, átbeszélés szerepét előtérbe helyezi; 12. Csökkentheti a kiégés valószínúségét, mértékét) szerepét. Az utolsó kérdés a válaszoló saját véleményét összegezte.

A válaszokat 1 -től 5 -ig tartó skálán vártuk, először a multidiszciplináris, majd az onkoterápiás onkoteam múködésére válaszoltak a kollégák. A válaszokból látható (1. táblázat), hogy a második lépcsős onkoteam szerepét a kollégák szinte minden vonatkozásban értékelték, illetve minimális mértékben, de hatékonyabbnak ítélték meg, mint a hagyományos onkoteamrendszer múködését. Egyedül a jogi biztonság tünik erősebbnek a multidiszciplináris onkoteam vonatkozásában, hiszen itt széles körben elfogadott és szabályozott múködésről van szó. A saját skálánkon 4 alatti átlagpontszámokat figyelhetünk meg 2 kérdés tekintetében, az egyik a beteg beleszólási jogkörének megítélése a saját kezelésébe, a másik pedig az orvos pszichés-érzelmi megnyilvánulásainak lehetőségét ítéli meg. Ebből sejthetően az orvoskollégák még nem kellő mértékúnek ítélik meg a kommunikációs csatornák múködését. $S$ végül talán a legfontosabb észrevétel, miszerint ez a fajta csapatmunka, felelősségmeg-

\begin{tabular}{l|l} 
1. táblázat & $\begin{array}{l}\text { A kérdőíves felmérés alapján számított átlageredmények és azok } \\
\text { standard devianciája a multidiszciplináris, illetve onkoterápiás } \\
\text { onkoteam-megbeszélések vonatkozásában }\end{array}$
\end{tabular}

\begin{tabular}{lcc|cc}
\hline Kérdés & \multicolumn{2}{c|}{ MD OT } & \multicolumn{2}{c}{ ONK OT } \\
\cline { 2 - 5 } & M & SD & M & SD \\
\hline $\begin{array}{l}\text { Fontos a tudásmegosztás, } \\
\text { az egymástól tanulás }\end{array}$ & 4,81 & 0,54 & 4,81 & 0,54 \\
$\begin{array}{l}\text { Hatékony módszer a szakorvosjelöl- } \\
\text { tek oktatására }\end{array}$ & 4,31 & 0,87 & 4,50 & 0,63 \\
$\begin{array}{l}\text { Jogi biztonságot ad a kezelóorvos } \\
\text { számára }\end{array}$ & 4,75 & 0,45 & 4,38 & 0,81 \\
$\begin{array}{l}\text { A döntés fontos része az orvosi } \\
\text { felelósség megosztása }\end{array}$ & 4,06 & 1,06 & 4,06 & 1,23 \\
$\begin{array}{l}\text { A beteg számára optimális terápia így } \\
\text { választható ki }\end{array}$ & 4,56 & 0,51 & 4,69 & 0,48 \\
$\begin{array}{l}\text { A beteg saját elvárása is beépíthetó } \\
\text { a döntésbe }\end{array}$ & 3,31 & 1,30 & 3,69 & 0,87 \\
$\begin{array}{l}\text { Új innovatív diagnosztika/terápia így } \\
\text { hatékonyabban meghatározható }\end{array}$ & 4,31 & 0,79 & 4,44 & 0,73 \\
$\begin{array}{l}\text { Evidenciaalapú, protokolláris terápiás } \\
\text { döntés érhetó el }\end{array}$ & 4,56 & 0,81 & 4,75 & 0,58 \\
$\begin{array}{l}\text { Csökkenti a kezelóorvos pszichés } \\
\text { terheit, érzelmi bizonytalanságát }\end{array}$ & 3,94 & 1,12 & 4,31 & 0,87 \\
$\begin{array}{l}\text { Teret hagy a saját gondolatoknak, } \\
\text { érzéseknek }\end{array}$ & 3,31 & 1,01 & 3,75 & 0,86 \\
$\begin{array}{l}\text { A csapatmunka, átbeszélés szerepét } \\
\text { elótérbe helyezi }\end{array}$ & 4,00 & 0,89 & 4,38 & 0,81 \\
$\begin{array}{l}\text { Csökkentheti a kiégés valószínúségét, } \\
\text { mértékét }\end{array}$ & 2,94 & 1,24 & 2,94 & 1,29 \\
$\begin{array}{l}\text { Fontosnak tartom (a saját) onkológusi } \\
\text { múködés szempontjából }\end{array}$ & 4,69 & 0,79 & 4,69 & 0,70 \\
\hline
\end{tabular}

MD OT = multidiszciplináris onkoteam; ONK OT = onkoterápiás onkoteam; $\mathrm{M}=$ átlag; $\mathrm{SD}=$ standard deviancia 
osztási és kibeszélési lehetőség rendkívül hasznos, de még mindig nem elég arra, hogy teljesen megelőzzük a fokozott pszichés megterhelés okozta kiégés lehetőségét.

\section{Megbeszélés}

A rákgyógyításban dolgozó orvosok, kezelőszemélyzet, illetve az onkológiai team tagjai nagy terhelésnek vannak kitéve mind fizikailag, mind lelkileg. Ez a pszichés teher abból adódik, hogy nap mint nap súlyos, sokszor gyógyíthatatlan betegekkel kerülnek kapcsolatba, állandóan ott lebeg a halál lehetősége és nagyon sokszor a tényleges bekövetkezte. Ugyanakkor a betegek nagy része reményt, optimizmust, biztatást vár az orvosoktól, ápolóktól. Sokszor gyorsan kell „váltani” egyik szituációról a másikra, és nincs idő tudatosítani, feldolgozni ezeket a nehéz érzéseket. A lelki megterhelés abból is fakad, hogy a páciensek nagy része nehéz és sokszor fájdalmas érzésekkel - köztük talán a két legmeghatározóbb a felfokozott szorongás és a lelki regresszió - küzd. Ezek az érzések pedig mind a kezelőszemélyzetre projektálódhatnak.

A gyógyítási folyamat középpontjában a beteg testi és lelki egészségének megőrzése, javítása áll. A páciensek egészségének megőrzése az egészségügyi ellátórendszer feladata, ezért fontos az abban dolgozó szakemberek testi és lelki egészségének megőrzése is [10]. A rákgyógyítás folyamata az abban részt vevő minden szereplö számára rengeteg nehézséggel és belső feszültséggel jár, mely nem megfelelő kezelés mellett kiégéshez vezethet [11, 12]. Természetesen, mint minden betegség esetén, ebben az esetben is a legjobb védekezés a megelőzés, illetve igen fontos a kiégés jeleinek korai felismerése is, lehetőséget biztosítva ezzel az esetleges lelki sérülések elkerülésére.

A gyógyítási folyamat középpontjában álló beteg számára a rákbetegséggel való megküzdés a legtöbb esetben élete legnehezebb feladata, melyet a korábban megtapasztalt és esetlegesen átélt lelki és fizikális nehézségek sok esetben meg sem közelítenek, hiszen az elmúlás képzete is megjelenik minden beteg lelki szemei előtt. Minden élő ember számára saját testi és lelki egészségének biztonsága a legfontosabb, amelyet a születésünk óta eltelt hosszú évek alatt sokszor megszokottnak és egyértelmûnek veszünk. A betegség lehetősége orvosi kivizsgálás vagy éppen öndiagnózis során merül fel, és a betegség gyanúja is hatalmas lelki terhet róhat az egyénre és a közvetlen hozzátartozókra. Az emberi együttérzés mint tehermegosztó lehetőség csakis a betegség gyanújával kapcsolatos információk megosztását követően kezd múködésbe lépni. Az egészségügyi dolgozók személyiségére elvileg jellemző a szociális érzékenység és az együttérzés, empátia. A gyógyítási folyamat során ez a képességük egyszerre előnyös és hátrányos is egyben. Az együttérzés következtében lesznek képesek a nehéz pillanatokban is motiváltan segítséget nyújtani, ugyanakkor a komplikált esetekben esetleges ütköző vélemények elle- nére középpontban tartani a páciensek érdekeit. Az egészségügyi dolgozók így a hosszabb távú, sikeresnek mondható gyógyítási folyamatok során fokozatosan válnak érzelmileg érintetté. A napi munka során tapasztalt kudarcok azonban sokszor ellenkezőleg hatnak a szakemberekre, hiszen a nehézségek sok esetben elterelik, megosztják a figyelmet, és ez kontraszelektíven hathat a teljesítményre [13]. Az együttérzés a normál orvos-beteg kapcsolat esetén mint motiváló tényező múködik a szakorvosok életében, hiszen e nélkül a beteg gyógyulási folyamatának kimenetele egyszerű szolgáltatásra vagy manuális munkavégzésre hasonlítana. A pozitív orvosbeteg kapcsolatot a gyógyítás folyamatában a gyógyítási szándék és a gyógyulási motiváció síkján megjelenő közös érdek múködteti. A betegség előrehaladtával a beteg és környezetének igénye a gyógyulás irányában nem vagy csak kismértékben változik, míg az orvosszakma által nyújtott protokolláris gyógyítási lehetőségek száma a betegség előrehaladtával csökken. A gyógyításra felesküdött, lelkiismeretes szakorvosok számára a lehetőségek szúkülése minden beteg esetében lelki teherként jelentkezik, mely a betegség előrehaladtával egyre fokozódik. Amennyiben a kiégés során a belső feszültség kezeletlen marad, úgy az egészségért és az életért folytatott küzdelem harcában könnyen a szakma képviselőin is negatív attitűdbéli változások jelei mutatkozhatnak.

Ezen lelki teher elviselésére, csökkentésére a szakorvosok több megoldást is alkalmazhatnak. Egyrészt pszichés védekezésként igyekeznek kettéválasztani a beteg személyét és a betegség tárgyát, avagy a túlzott bevonódást elkerülendő, igyekeznek a betegek felé irányuló reális emberi gondoskodás érzete mellett bizonyos távolságtartással, objektíven megközelíteni azok betegségét („detached concern" stratégia), ám ennek az egyensúlynak a megtalálása nehéz feladat $[14,15]$. Másrészt a csoportmunka tehermegosztó lehetôségét segítségül hívva igyekeznek enyhíteni a lelki oldalról érkező nyomáson. A megbeszélések megfelelő teret biztosítanak, hogy a csoporttagok megismerhessék mások dilemmáit, illetve azon esetekben, amikor az orvos szükségesnek érzi, tanácsot kérhet kollégáitól a beteg ellátását, további kezelését illetően. Az onkoteam-megbeszéléseken a szakmai paraméterek mentén történő döntéshozatal mellett szóba kerülhet a betegekkel kapcsolatos lelki nehézségek megbeszélése, megvitatása is, mely hozzájárulhat a kezelőorvos lelkiismeretének megnyugtatásához.

A rákgyógyításban alkalmazott kezelések protokolláris jellege sok esetben módosulhat a beteg igénye alapján: a beteg sokszor úgy hoz meg döntéseket a saját sorsával, életével kapcsolatban, hogy nincs birtokában azon tudásnak, mely döntéseinek lehetséges következményeire figyelmeztetné. A fenti, kiszolgáltatottnak tűnő állapot a páciensben érthető módon belső feszültséghez vezet, mely önmagával hozza a témával kapcsolatos ismeretanyagának reális vagy irreális bóvítését. Az orvostól kapott instrukciók, tanácsok kiegészülnek önképzés révén elsajátított egészségügyi tartalmakkal, korábbi ismere- 
tekkel és egyéb véleményekkel is [16]. Végső soron a gyógyítási folyamatból annyi realizálódik, amennyit a beteg az együttmúködése alapján elfogadhatónak érez. A betegoldali döntési kényszer okozta belső feszültség sok esetben, részben visszahatva, áthelyeződik a kezelőorvosokra is, akik attitűdjeiknek megfelelően próbálják értelmezni, átélni a betegek állapotát, helyzetét, illetve ezek alapján a rendelkezésre álló rövid idókeretben türelmesen választ adni a beteg életét befolyásoló kérdésekre.

Az orvos-beteg kommunikációs csatorna korlátai miatti feszültség megvitatásának egyik lehetséges színterét éppen az onkoteam-megbeszélések jelentik. A különböző munkacsoportok az élet más területeihez hasonlóan számos haszonnal (és teherrel is) járnak az abban tevékenykedő tagok számára. A jól múködő csoport előnyeit elsősorban azon tagok élvezhetik, akik tevékenyen részt vesznek a csoport munkájában, támogatva annak múködését, betartva annak külső és belső szabályait. A betegek oldaláról igénybe vehető lehetőségek közül ezzel párhuzamosan kiemelendő az öntevékeny csoportok, fórumok, esetlegesen egyéni pszichoterápiás konzultációk nyújtotta érzelmi megosztás mint a trauma feldolgozásának lehetôsége. Sok esetben azonban a betegeknek nincs módjuk és lehetőségük a sokszor igen nagy költségekkel járó testi gyógyulási folyamatokkal párhuzamosan jelentkező negatív lelki folyamatok kontrolljára is. A fenti helyzetben kialakuló depresszív állapot érintheti a beteget és az ellátásában segítő hozzátartozókat, de végső soron a kezelőorvost is.

$\mathrm{Az}$ onkoteam-megbeszélésen részt vevő rezidens orvosok kezdetben csak külső megfigyelőként közremüködnek a csoport munkájában, érzékenyítve magukat a döntéshozatal környezetéhez és annak következményeihez. A fiatalabb orvoskollégák az elméletben megtanult gyógyítási folyamatot sok esetben mentoraik segítségével, egyszerúbb eseteken keresztül kezdik el gyakorolni. A tanulási folyamat néhány esetben igen nagy kihívást jelent a gyakorló orvosoknak; a lelki teher megosztására nem minden esetben jut elegendő idő számukra a csoportmunka alatt, annak birtokában azonban szúkebb körben lehetőség nyílik terheik megosztására a mentorukkal folytatott értékelő, levezető megbeszélés során. Az egyes, rezidensek számára átadott esetek progresszív jellege mind mennyiségben, mind összetettségben biztosítja a gyakorló orvos túróképességének megfelelö pszichés kondicionálását.

Összességében ezeket a mentális és pszichés terheket egyedül feldolgozni nem egyszerú, ezért lehet fokozott szerepe egy ilyen közösségben a kommunikációnak és a csoportmúködésnek. Az onkoteam mint csoport múködésében fontos a vezető személyisége, határozottsága, a tagok tudása, tapasztalata, és alapvető a következő szempont is: a csoportnak legyen megtartó ereje, és biztonságot nyújtson a tagjai számára. Ebben az esetben tud megjelenni a „terápiás” hatás, avagy jó esetben a kiégést megelőző hatás. A már többször említett kiégés pedig a rendezett és hatékony orvos-beteg kapcsolat egyik leg- komolyabb „rákfenéje”, kialakulása az empátia elvesztéséhez, a gyógyítás hatékonyságának romlásához vezethet, a kezelőszemélyzetnél pedig érzelmi kimerültség, a kudarcélmények fokozott megélése, deperszonalizáció vagy cinizmus jelentkezik, és végső soron akár szomatikus betegségek alakulhatnak ki $[17,18]$.

A magyar orvosi történelem szempontjából különösen fontos, hogy a pszichoanalitika és az orvosi csoportmúködés egyik legkomolyabb nemzetközi szaktekintélye, dr. Bálint Mihály hazánk szülötte volt, és az ő nevéhez füződik az ún. Bálint-csoportok megalapítása, melyek célja az önismeret, a problémamegoldó és a kommunikációs képesség fejlesztése, a gyógyítással kapcsolatos stresszhelyzetek intenzitásának csökkentése és a kiégés megelőzése. Az elmúlt több mint 50 évben a Bálint-csoportok számtalan országban és számtalan intézményben az ellátás szerves részeivé váltak, és a definiált céloknak megfelelően nemcsak a pszichiátria területén, hanem az egészségügyi ellátás más szegmenseiben is bizonyították fejlesztő és megelőző hatásukat [18-20]. A Bálint-csoport-megbeszélések általában heti rendszerességgel, másfél óra időtartamban, 1-2 csoportvezetővel, 10-15 résztvevővel kerülnek megrendezésre. Gyakorlatilag betegreferálóként múködnek, ahol az orvosi szempontból vagy emocionálisan kihívásnak, problémásnak gondolt klinikai esetek részletes elmesélését követően, a második lépésben a kezelőorvos meghallgatja kollégái kérdéseit, javaslatait, esetleg érzelmi reakcióit. E kommentároknak azonban célirányosnak és betegorientáltnak kell lenniük. A csoportmúkiödés szempontjából itt is nagyon fontos a vezető tapasztalata, személyisége [21]. Eredményes múködés esetén a referáló orvosok egyfajta biztonságot és lelki megkönnyebbülést érezhetnek, és konstatálják, hogy a többi kolléga is sokszor hasonló dilemmákkal küszködik. Nagyon fontos persze, hogy mindvégig a beteg maradjon a középpontban, és a pácienssel kapcsolatban érzett orvosi felelősség és humán reláció egy pillanatra se kerüljön háttérbe. Egyébiránt több tapasztalat ismert azzal kapcsolatban is, hogy a megfelelö csoportmúködés a betegek gyógyítási hatékonyságát és gyógyulási esélyét is javíthatja [13,22].

Magyarországon 2011-ben Csörsz Ilona számolt be arról, hogy orvostanhallgatók, illetve pszichológustanulók esetében többek között a Bálint-csoport-megbeszélések is fejlesztik a személyiséget, a szakmai karaktert és a problémamegoldó készséget [23]. Más közlemények is ismertek azzal kapcsolatban, hogy a Bálint-csoport-referálók fejlesztik az orvostanhallgatók, szakdolgozók, nővérek, önkéntes segítők kommunikációs és problémamegoldó képességét [13, 18, 24, 25]. A rákgyógyítás területén is ismertek ilyen megbeszélések; egy több évtizede keltezett leírás hangsúlyozza a fórum szerepét az archaikus és a betegvesztés okozta félelmek csökkentésében, az orvos-beteg kapcsolat javításában és a daganatos beteg izolációjának feloldásában [20].

Érdekes lehet egy magyar kutatás, mely a súlyos betegekkel foglalkozó egészségügyi dolgozók testi-lelki álla- 
potát mérte fel a 2000-es évek elején [26]. A végeredmény: az egészségügyi dolgozók körében (orvosok, ápolók) magasabb a kimerültség, a stresszfüggő testi-lelki tünetekkel való együttélés, a káros szenvedélyek aránya, gyengébb a szociális kapcsolatok rendszere. Ezért is fontos a kiégés megelőzése és az ellátószemélyzet lelki világának karbantartása. Az onkológiai ellátás során pedig nem egy-két alkalommal találkozik a kezelőorvos a beteggel, hanem hosszú hónapok, évek során hosszabb távú együttmúködés alakul ki közöttük. Maga ez a kapcsolat is a gyógyítás fontos eszköze. Ahogy említettük, ebben a kapcsolatban az érzelmi odafordulás, a beteg felé irányuló empátia nagyon hasznos, ugyanakkor nagyon veszélyes is tud lenni. Hasznos és szükséges, mert segítségével megvalósítható az egyénre szabott kezelés, a bizalom kiépítése és a beteg terápiakövető magatartásának serkentése. Veszélyes, mert pont a túlzott érzelmi bevonódás segíti elő a kudarcélmény intenzív átélését, a kiégést vagy az ún. másodlagos traumatizációt. Mindezek megelözésében segíthet a megfelelő munkahelyi légkör és a csapatmunka érzése.

Ám a helyzet megoldása természetesen nem ilyen egyszerü, a csapatmunka során is jelentkezhetnek nehézségek. Azon esetekben, amikor a teamnek a gyakorlati korlátokat figyelmen kívül hagyva több döntést kell hoznia, mint amennyi az optimálisan megvitatható esetek száma, a kooperáció csökkenhet, és ez a gyógyítási munka minőségromlását okozhatja. A fentieket figyelembe véve a kooperatív együttmúködés területén kiemelten fontos, hogy a döntések meghozatalára elegendő idő és szakember álljon rendelkezésre. A fentieket figyelembe véve kiemelten fontos a hatékony kommunikációs csatornák múködtetése, elegendő időt biztosítva a döntéshozatalban részt vevő minden egyes szakember számára, hogy véleményét kifejthesse. Egy csoporton belül az elméletileg lehetséges kapcsolatok száma az $\mathrm{N} \times(\mathrm{N}-1) / 2$ képlettel adható meg. Ezen kapcsolatok száma alapján elmondható, hogy öt szakorvosból álló team esetén $5 \times$ $(5-1) / 2=10 \mathrm{db}$, míg tíz szakemberból álló csoport esetén már $10 \times(10-1) / 2=45$ különböző kapcsolat lehetséges. Adott időkorlátot feltételezve, a döntéshozatali mechanizmus javítható a kommunikáció optimalizálásával, de könnyen belátható, hogy túl magas létszám esetén a kooperáció hatékonysága csökkenhet, amennyiben minden résztvevő ki szeretné nyilvánítani véleményét az adott döntéssel kapcsolatban. A levezető elnök feladata, hogy irányítsa a döntéshozatali mechanizmus során az együttmúködést, ezzel biztosítva a helyes időgazdálkodást, megtartva annak tartalmi és szerkezeti integritását. A másik oldalról az is átlátható, hogy egynéhány résztvevő nem alkothat minden szempontból aktív teamet. A csoporton belül az egyes csoporttagok felelősségi köre kettős. Egyrészt felelősséget vállalnak a saját maguk által prezentált beteginformációk valódiságáért és a tervezett terápiás kezelés szakmai színvonaláért, másrészt építő jellegú hozzászólásaikkal segítik, támogatják kollégáik munkáját. Ugyanakkor az egyének tudása és nézőpontja összegződik a csoportos döntésben, mely biztosan több, mint a résztvevők tudásának „összege”, és a komplex problémára meghozott döntésért való felelősséget az egész csoport viseli, nem az egyén, egyedül, lelkileg magányosan.

Megfelelő feltételek és optimális terhelés mellett azonban képes a csoport a komplex problémák hatékony megoldására. Az új eljárásrendek és protokollok megismerése és elsajátítása azonban mind a rezidensek, mind a praktizáló szakorvosok számára fontos és elengedhetetlen feltétel szakmai munkájuk hatékony végzéséhez, melynek egyetlen közös célja a beteg testi és lelki egészségének megőrzése, életminőségének javítása.

\section{Következtetés}

A gyógyítás maga is komoly pszichés teher, hiszen az orvos is átvesz sok mindent a beteg lelki megpróbáltatásaiból, ugyanakkor szorong a gyógykezelés sokszor bizonytalan kimenetele miatt. Ebból a szempontból kiemelt szereppel bír a rákbeteggyógyítás, hiszen itt a pszichés teher fokozott, és nagyobb a kiégés veszélye. Persze nagyon fontos, éppen a betegek érdekében, a kezelőorvos lelki egyensúlyának lehetőség szerinti megtartása. Ebben játszhatnak szerepet a különböző csoportmúködések, kommunikációs és ventilációs lehetőségek, avagy az onkológiában a jól múködő onkoteamek, amelyek egyfajta kibeszélő „Bálint-csoportként” csökkenthetik a terheket és a kiégés veszélyét. Ezen múködés ismertetése és elemzése során szerettük volna bizonyítani, hogy a mai világban az individuum felértékelődése kapcsán a gyógyítók felelőssége is fokozott, és ha nem lehet is minden problémát elkerülni a gyakoribb kommunikációval, csoportmunkával, mégis egyfajta minőségbiztosításként a jól szabályozott közösségi feladatvállalás segít a mai komplex világban, illetve a gyógyítás fokozott biztonságának a betegek felé történő továbbításában.

Anyagi támogatás: A szerzók nem részesültek a közlemény megírásával kapcsolatos pénzügyi támogatásban.

Egyéb támogatás: A szerzők részben résztvevői az EFOP1.8.0-VEKOP-17 (Egészségügyi ellátórendszer szakmai módszertani fejlesztése; "Jó-gyakorlat”, M. L.) és a GINOP-2.2.1-15-2017-00067 („Hálózatos analitikai és adathasznosítási lehetőségek az egészségügyben”, M. L., S. H.) országos pályázatoknak. Ezen projektek a közlemény megírását közvetlen módon nem támogatták, de oktatási anyagok elkészítése, konzultációk kapcsán sokban segítették a közlemény tartalmi összeállítását.

Szerzői munkamegosztás: S. H.: Adatgyüjtés, a közlemény legnagyobb részének megírása. F.-M. M., H. A., K. E.: A közlemény szakmai véleményezése, kiegészítése. 
M. L.: Az alapteória megalkotása és részben a közlemény megírása, szakmai véleményezése. A cikk végleges változatát valamennyi szerző elolvasta és jóváhagyta.

Érdekeltségek: A szerzőknek a közlemény tartalmával kapcsolatban semmilyen anyagi vagy más természetű érdekeltségük nincs.

\section{Köszönetnyilvánítás}

Ezúton mondunk köszönetet valamennyi, a megbeszéléseken részt vevő kollégának a hatékony együttmúködésért.

\section{Irodalom}

[1] Hollunder S, Herrlinger U, Zipfel M, et al. Cross-sectional increase of adherence to multidisciplinary tumor board decisions. BMC Cancer 2018; 18: 936.

[2] Rosell L, Alexandersson N, Hagberg O, et al. Benefits, barriers and opinions on multidisciplinary team meetings: a survey in Swedish cancer care. BMC Health Serv Res. 2018; 18: 249.

[3] Pillay B, Wootten AC, Crowe H, et al. The impact of multidisciplinary team meetings on patient assessment, management and outcomes in oncology settings: a systematic review of the literature. Cancer Treat Rev. 2016; 42: 56-72.

[4] Specchia ML, Frisicale EM, Carini E, et al. The impact of tumor board on cancer care: evidence from an umbrella review. BMC Health Serv Res. 2020; 20: 73.

[5] Kásler M, Pikó B, Poller I, et al. Observations and suggestions for the organization and work of oncology patient care teams. [Észrevételek és javaslatok az onkoteamek felépítésére és múködésére.] Magy Onkol. 2008; 52: 321-326. [Hungarian]

[6] Hahlweg P, Didi S, Kriston L, et al. Process quality of decisionmaking in multidisciplinary cancer team meetings: a structured observational study. BMC Cancer 2017; 17: 772.

[7] Mangel L, Kövér E, Szilágyi I, et al. Novel quality assurance method in oncology: the two-level, multi-disciplinary and oncotherapy oncology team system. [Új típusú minőségbiztosítás az onkológiában: A kétlépcsős (multidiszciplináris és onkoterápiás) onkoteamrendszer.] Orv Hetil. 2012; 153: 1984-1991. [Hungarian]

[8] Mangel L, Lukács M, Hajnal A, et al. The first experiences with the palliative tumour board discussions in the University of Pécs. [Az első tapasztalatok a palliatív onkoteamrendszer múködésével kapcsolatban a Pécsi Tudományegyetemen.] Orv Hetil. 2020; 161: 1423-1430. [Hungarian]

[9] Mattes MD, Gerbo R, Dattola RM. Tumor board shadowing for medical students as a means of early exposure to multidisciplinary oncology education. J Am Coll Radiol. 2017; 14: 253-255.

[10] Murali K, Makker V, Lynch J, et al. From burnout to resilience: an update for oncologists. American Society of Clinical Oncology Educational Book 2018; 38: 862-872.

[11] Tari, A. Psychosocial processes in tumor board discussions. In: Horti J, Riskó Á. (eds.) Psycho-oncology in practice. [Pszichoszociális folyamatok az onkológiai teamben. In: Horti J, Riskó Á. (szerk.) Onkopszichológia a gyakorlatban.] Medicina Könyvkiadó, Budapest, 2. online kiadás, 2017; pp. 498-502. [Hungarian]

[12] Fülöp E, Devecsery Á, Csabai M. The connection between emotional burden and burnout in psychiatry residents. [Az érzelmi bevonódás és a kiégés összefüggései pszichiáter rezidensek köré ben.] Mentálhig Pszichoszom. 2012; 13: 201-217. [Hungarian]

[13] Abeni MS, Magni M, Conte M, et al. Psychological care of caregivers, nurses and physicians: a study of new approach. Cancer Med J. 2014; 3: 101-110.

[14] Lief HI, Fox RC. Training for 'detached concern' in medical students. In: Lief HI, Lief VF, Lief NR (eds.) The psychological basis of medical practice. 1st edn. Hoeber Medical Division of Harper \& Row, New York, NY, 1963; pp. 12-35.

[15] Lampert B, Unterrainer C, Seubert CT. Exhausted through client interaction - Detached concern profiles as an emotional resource over time? PLoS ONE 2019; 14: e0216031.

[16] Feith HJ, Szőke A, Ábrám B, et al. Knowledge, experience and attitudes of laymen in oncological health services. [Laikusok onkológiai ellátáshoz kapcsolódó ismeretei, tapasztalatai és attitűdjei.] Orv Hetil. 2016; 157: 1314-1319. [Hungarian]

[17] Hlubocky FJ, Back AL, Shanafelt TD. Addressing burnout in oncology: why cancer care clinicians are at risk, what individuals can do, and how organizations can respond? American Society of Clinical Oncology Educational Book 2016; 36: 271-279.

[18] Bar-Sela G, Lulav-Grinwald D, Mitnik IJ. "Bálint group" meetings for oncology residents as a tool to improve therapeutic communication skills and reduce burnout level. J Cancer Educ. 2012; 27: 786-789.

[19] Yazdankhahfard M, Haghani F, Omid AJ. The Bálint group and its application in medical education: a systematic review. J Educ Health Promot. 2019; 8: 124.

[20] Meerwein F, Kauf S, Schneider GZ. Remarks on the physicianpatient relationship with cancer patients. Prerequisites, function, and goal of so-called Bálint groups in an internal-oncological department. [Bemerkungen zur Arzt-Patientenbeziehung bei Krebskranken. Voraussetzungen, Funktion und Ziel sogenannter "Balintgruppen" an einer internistisch-onkologischen Abteilung.] Z Psychosom Med Psychoanal. 1976; 22: 278-300. [German]

[21] Tschuschke V, Flatten G. Effect of group leaders on doctors' learning in Bálint groups. Int J Psychiatry Med. 2019; 54: 8396.

[22] Muench J. Balint work and the creation of medical knowledge. Int J Psychiatry Med. 2018; 53: 15-23.

[23] Csörsz I. Social psychological determinants of the formation of medical students' professional identity. Possibilities of development. [Az orvosi hivatásszemélyiség alakulásának társaslélektani meghatározói és fejlesztésének lehetőségei.] Orv Hetil. 2011; 152: 475-480. [Hungarian]

[24] Shorer Y, Rabin S, Zlotnik M, et al. Bálint group as a means for burnout prevention and improvement of therapist-patient relationship in a general hospital - the Soroka experience. Harefuah 2016; 155: 115-118.

[25] Yao LY, Xiang ML, Ye ZH, et al. Intervention study of compassion fatigue of oncology nurses in Bálint group activities. Zhonghua Lao Dong Wei Sheng Zhi Ye Bing Za Zhi 2017; 35: 910913. [Chinese]

[26] Hegedús K, Riskó Á, Mészáros E. The physical and mental condition of health care workers dealing with severe diseases. [A súlyos betegségekkel foglalkozó egészségügyi dolgozók testi és lelki állapota.] Lege Artis Med. 2004; 14: 786-793. [Hungarian]

(Mangel László dr., Pécs, Édesanyák útja 17., 7624 e-mail: mangel.laszlo@pte.hu)

A cikk a Creative Commons Attribution 4.0 International License (https://creativecommons.org/licenses/by/4.0/) feltételei szerint publikált Open Access közlemény, melynek szellemében a cikk bármilyen médiumban szabadon felhasználható, megosztható és újraközölhető, feltéve, hogy az eredeti szerző és a közlés helye illetve a CC License linkje és az esetlegesen végrehajtott módosítások feltüntetésre kerülnek. (SID_1) 